\title{
コロナウィルスの感染対策に有用な室内環境に関連する研究事例の紹介
}

\author{
篠原直秀"
}

\author{
国立研究開発法人産業技術総合研究所７305-8569 茨城県つくば市小野川16-1
}

\section{Reference researches on indoor environment valuable for infection control of coronavirus}

\author{
Naohide SHINOHARA*
}

\begin{abstract}
National Institute of Advanced Industrial Science and Technology, 16-1 Onogawa, Tsukuba, Ibaraki 305-8569, Japan
要 旨

2020年の春時点で，日本を含む世界中で新型コロナウィルス(SARS-CoV-2)の感染が猛威を振るっており, 三密を避けることなど，より一層の感染対策が求められている。本稿では，室内環境における感染対策に関 わる情報を収集・整理した。感染者が呼吸・会話・咳・くしゃみなどをすると，ウィルスを含む飛沫が環境 中に飛散する。会話や咳で飛散する大きな粒子は，多くの場合 $2 \mathrm{~m}$ 以内に床面に沈着するが，室内の気流に よっては $5 \mathrm{~m}$ 程度飛散することもある。また, 飛沫核などの小さな粒子は, 沈着せずに数時間むしくはそれ 以上室内を漂う可能性がある。室内空気中からウィルスが除去される経路としては, 床面や壁面への沈着, 換気による屋外への排出，ウィルスの不活化があるが，無風の状態では $10 \mu \mathrm{m}$ 超えるサイズの粒子ではほ ぼ沈着で除去されるが, 数 $\mu \mathrm{m}$ 以下の粒子では換気と不活化の寄与が大きい。室内を漂うエアロゾル上の新 型コロナウィルスの不活化の半減期は1.1時間程度であり，換気回数 1 回 $/ \mathrm{h}$ の場合よりも減衰への寄与は小さ い。日本の一般家屋の日常生活時の換気回数は, 春夏で1.2-1.7回 $/ \mathrm{h}$, 秋冬で 0.6 回 $/ \mathrm{h}$ 程度であり, 病室などで感 染対策として取られる換気回数よりはるかに低い。空開け換気は室内濃度を低減させるのに非常に有効であ るが，屋外の風向や風速によっては十分な換気量が得られないケースもある。空気清浄機については，コロ ナウィルスについての研究はないが, HEPAフィルター(High Efficiency Particulate Air Filter)を用いた場合に は，ウィルスについても一定の効果が認められている。
\end{abstract}

Key words: 室内環境(indoor environment)，コロナウィルス(coronavirus), 粒径分布(size distribution), 飛沫(droplet), 換気(ventilation), 沈着(deposition), 不活化(inactivation)

\section{1. 緒言}

2020年の春時点で，世界中で新型コロナウィルス の感染が猛威を振るっている。日本国内での感染も 感染拡大期に入っており，より一層の感染対策が求 められている。室内環境についても, 三密(換気の 悪い密閉空間, 近距離での会話や発声, 手の届く距 離に大人数)を避けることが推奨され，換気の励行 も各所で行われている。この状況の中で，室内環境 に関連する既存の研究結果が対策に有用なケースも 少なからずあると考えられるため，ウィルスの感染 経路, 飛沫の大きさ之室内での飛散, 室内空気中で の飛沫核の挙動とウィルスの不活化, 室内の換気, 室内空気の清浄化, 室内に打ける沈着之再飛散に関
して情報を収集・整理した。

\section{2. ウィルスの感染経路}

現在感染が拡大しているコロナウィルスなどのウィ ルスは，接触を介した感染とエアロゾルを介した感 染により広がるとされている1。コロナウィルスの 感染経路としても, 接触感染とエアロゾルを介した 感染が起きていると考えられている2-90。接触感染は, 握手や八グなどで生じる直接接触とドアノブや家電 や消費者製品などに触れることにより生じる間接接 触によるものに分けられる1。エアロゾルを介した 感染は，咳やくしゃみや発声に伴って排出される飛 沫(主に>5 $\mu \mathrm{m}$ の液滴)によるもの(いわゆる飛沫感染)

*Corresponding author（責任著者） E-mail: n-shinohara@aist.go.jp, Tel: 029-861-8030

受付：2020年4月28日（Received: 28 April 2020)

受理：2020年5月25日 (Accepted: 25 May 2020) 
とそれらの水分が蒸発して残る飛沫核 $(<5 \mu \mathrm{m}$ の粒 子)によるもの(いわゆる空気感染)に分けられる1。 本稿では，以下に，飛沫及び飛沫核を介した感染対 策に有用だと思われる情報を整理する。

\section{3. 飛沫の大きさと室内での飛散}

ウィルス自体の大きさは, $30 \mathrm{~nm}$ (rhinovirus $\left.{ }^{7}\right), 80$ $120 \mathrm{~nm}$ (influenza $^{8)}$ ), 50-200 nm (SARS-CoV-29) な どとされているが，それらはさらに大きい飛沫(液 滴)の中に含まれて気中に出てくる。話すときや咳 をしたときの呼気中の飛沫の大きさは, 数百 $\mathrm{nm}$-数 $\mathrm{mm}$ であり, 個数濃度としては $2 \mu \mathrm{m}$ 前後と $120-150$ $\mu \mathrm{m}$ 辺りにピークを持つサイズ分布である ${ }^{100}$ 。咳を した時の液滴を $0.35 \mu \mathrm{m}$ から $10 \mu \mathrm{m}$ まで測定したと ころ, 小さい粒子ほど個数が多く，インフルエンザ 患者で咳一回当たり 75000 個/咳, 治癒後は咳一回当 たり52000個/咳の粒子が含まれているという報告む ある ${ }^{11}$ 。病院の飛沫中のコロナウィルスについては, $<1 \mu \mathrm{m}$ のアロゾルでは検出されず，1-4 $\mu \mathrm{m}$ で> $4 \mu \mathrm{m}$ よりきいもしくは同程度検出されたという 報告 ${ }^{12)},<0.25->2.5 \mu \mathrm{m}$ で検出されたが粒径間に明ら かな傾向はないという報告 ${ }^{13}$ があるが，これらは今 のところ査読前原稿であり，また例数も少なく，今 後の知見の集積が待たれる。

$60 \mu \mathrm{m}$ を超える大きな飛沫は, 通常の呼吸 $(<1$ $\mathrm{m} / \mathrm{s})$ では感染者から50 cm以内, 話す場合 $(<5 \mathrm{~m} / \mathrm{s})$ には $1 \mathrm{~m}$ 以内，咳をする場合 $(<10 \mathrm{~m} / \mathrm{s})$ には $2 \mathrm{~m}$ 以内, くしゃみをする場合 $(20-50 \mathrm{~m} / \mathrm{s})$ には3-6 mで, 重力 沈降で気中からなくなるもしくは水分が蒸発して飛 沫核になる ${ }^{14)}$ ここれらの研究を元にして, 現在多く の国において $2 \mathrm{mp6}$ feet (約1.8 m) のソーシャルディ スタンシングを取ることが求められている(2014年

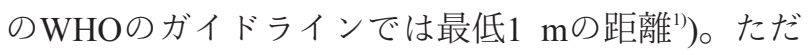
し，換気などの室内の気流条件によっては，通常の

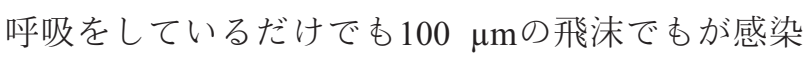
者から5 m程度まで飛散する可能性もある ${ }^{15}$ 。新型 コロナウィルスについても，レストランにおいて感 染者のテーブルから空調の気流に沿った直線上のテー ブルのみで感染が確認されたという報告があり, 気 流によって飛沫が拡散した可能性も示唆されてい $3^{16)}$ 。

飛沫の水分が蒸発する時間は，0.5-20 $\mu \mathrm{m}$ の粒子 では 0.8 秒 $17,50 \mu \mathrm{m}$ の粒子で 2 秒， $200 \mu \mathrm{m}$ の粒子で あ24秒(14)であり，環境中と水分量が平衡となった飛 沫核となる。飛沫の成分となる粘液(mucus) は，水 分以外の大部分が糖タンパク質であり, 残りがナト リウム, カリウム, 塩素, 乳酸塩などが含まれてい る ${ }^{18)}$ 。飛沫核の組成は，89\%がタンパク質で，10\%が $\mathrm{NaCl}, 1 \%$ が肺サーファクタントだとする報告もあ る ${ }^{19)}$ 。また, 蒸発後の飛沫核の大きさ(直径) は湿度 によって異なるとされており, 飛沫を模した $\mathrm{NaCl}$ (塩化ナトリウム)の液滴を用いた実験と糖タンパク 質を含んでいた場合の推定結果 $(\mathrm{NaCl}$ 液滴と糖タン パクを含む液滴の場合の違いは4\%程度しかない)か ら, 相対湿度 $50 \%$ 以下では元の飛沫の大きさの $40 \%$ 程度, 相対湿度 $90 \%$ では元の飛沫の大きさの $50 \%$ 程 度になる ${ }^{20)}$ 。これらの飛沫核については, 一定時間 の間, 室内空気中を漂うことになる。

\section{4. 室内空気中での飛沫核の挙動とウィルスの不活化}

室内に招けるエアロゾル中のウィルスは，換気・ 沈着・不活化によって, 感染に寄与しなくなる ${ }^{200} 。$ 沈着之は, 重力沈降や気流による慣性や拡散などに よって, 室内の表面に付着して空気中から除かれる ことを指す。相対湿度 $50 \%$ の条件下の咳をして 10 分 後には, $1 \mu \mathrm{m}, 10 \mu \mathrm{m},>25 \mu \mathrm{m}$ エアロゾル中のイ ンフルエンザゥィルスは, 重力沈降によっては $0.7 \%$, $51.2 \%, 98.8 \%$ 減少し，換気によっては換気回数 1 回 $/ \mathrm{h}$ 及び10回/hの場合でサイズに拠らず15\%及び $81 \%$ 減 少し，不活化によってはサイズに拠らず15\%減少す る(それぞれ独立に計算しているため合計は $100 \%$ を 超えていることに注意 $)^{20)}$ 。つまり, 大きい粒子は沈 着により空気中から除かれるが, 小さい粒子では換 気により屋外に排出されるか不活化されるのを待つ ことになる。ただし，空調・換気のあるオフィスな どでは，一部は換気口を経由して屋外に排出される が，一部は室内に再循環される。エアロゾル中のイ ンフルエンザは湿度が高いほど不活化しやすく，ま た沈着しにくい。相対湿度 $90 \%$ と相対湿度 $10 \%$ とを 比べると，10分，30分，1時間では，失活速度は，1.4 倍, 2.7倍, 7.3倍に, 沈着速度は1.7倍, 2.0倍, 2.2倍に なる ${ }^{20)}$ 。実験室 (温度 $22-23^{\circ} \mathrm{C}$, 相対湿度 $40 \%$ )で発生 させたエアロゾル中の新型コロナウイルス (SARSCoV-2)の生存半減期の中央值は 1.1 時間( $95 \%$ 信頼区

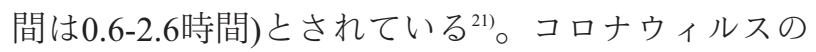
湿度依存性はよくわかっていないが，インフルェン ザと比べて, 不活化するのにより長い時間を要する 可能性がある。 


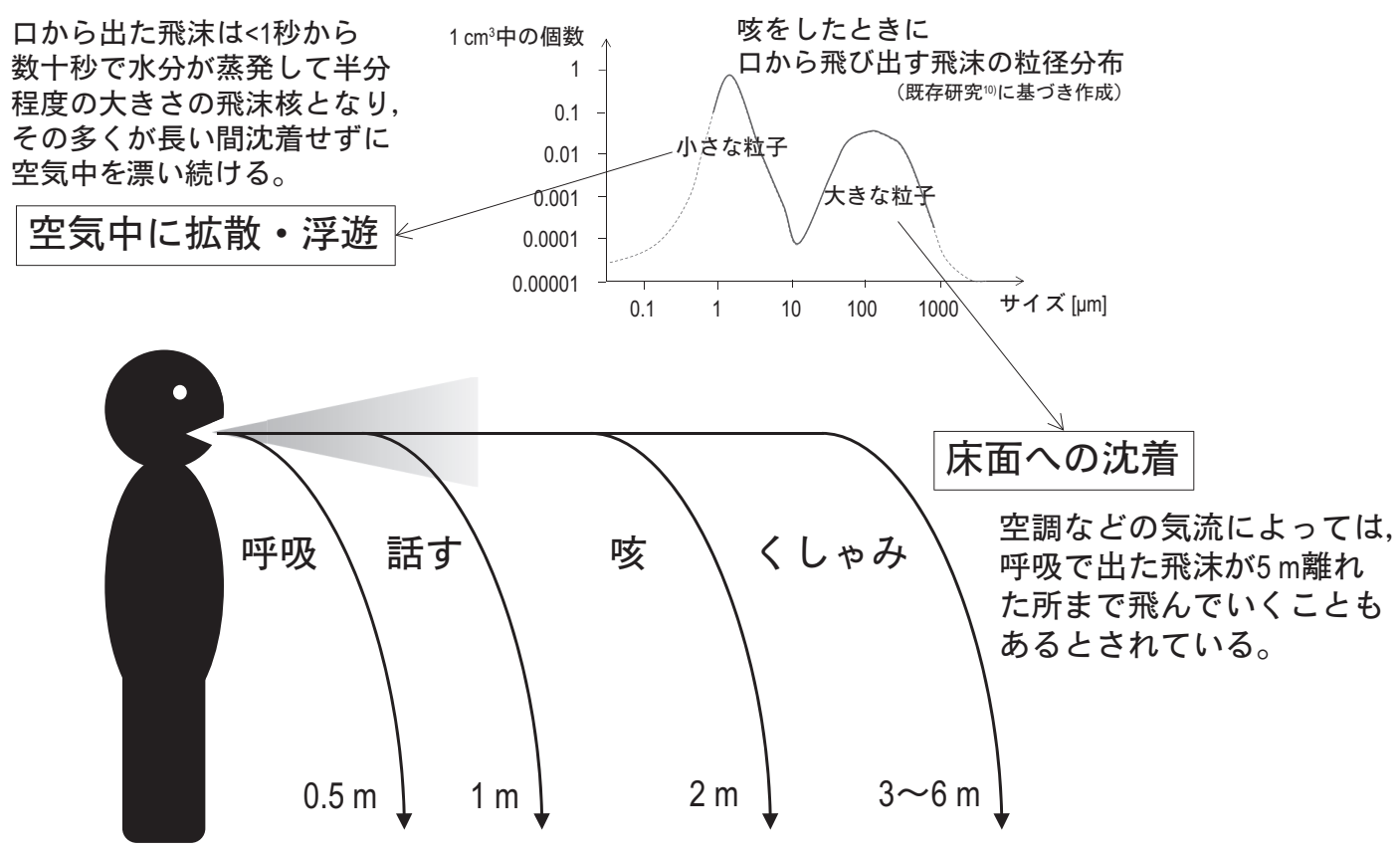

Fig.1 Size and behavior of droplet

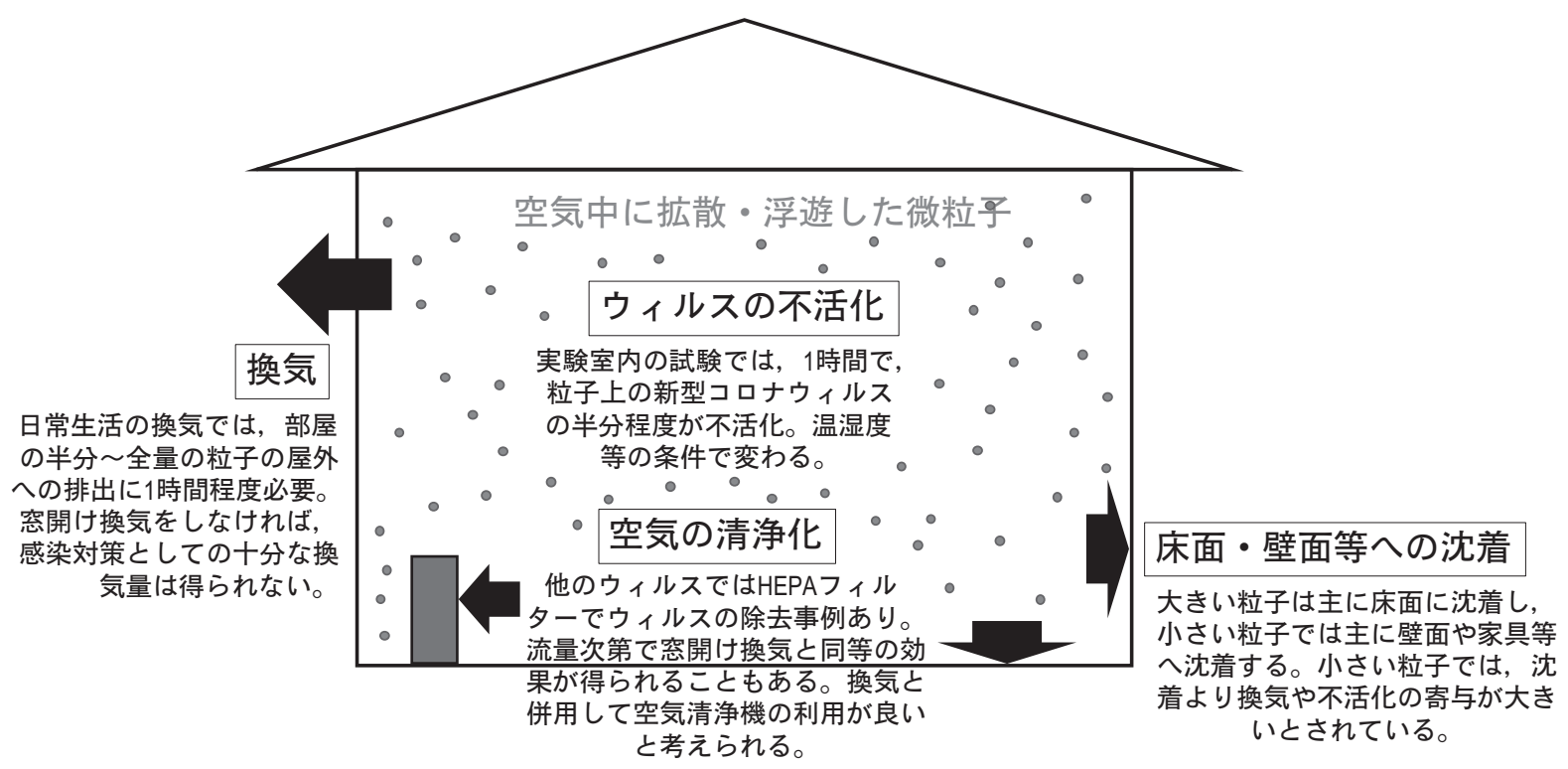

Fig.2 Removal mechanism of virus from indoor environment

\section{5. 室内の換気}

日本の住宅は，建築基準法で新築時に 0.5 回 $/ \mathrm{h}$ 以上 の機械換気設備の設置が義務付けられている。日常 生活を送っている間の換気回数は, 春, 夏, 秋, 冬で 1.2, 1.7, 0.6, 0.6回/hであり, 春や夏で換気回数が高 くなっているのは空開け時間が長いためだとされて いる ${ }^{22}$ 。海外の調査で屯空開け換気をしている住宅 としていない住宅では, 3.5 回 $/ \mathrm{h}$ と 0.8 回 $/ \mathrm{h}$ (夏季)及び 2.5 回 $/ \mathrm{h}$ と 0.5 回 $/ \mathrm{h}$ (年間) と換気に大きな違いがみられ
$3^{23}$ 。室内で単回の $\mathrm{PM}_{2.5}$ 発生があった場合には, 10 分以内の空開け換気で室内の $\mathrm{PM}_{2.5}$ 濃度は外気レベ ル以下に落ちるとされている24)。空を開けている場 合でも, 外気の風速之風向や空の形状によって換気 回数は 0.5 回 $/ \mathrm{h}$ から数 10 回 $/ \mathrm{h}$ と大きく変わりうること がモデル計算によって報告されており，空開けをし ても換気量が大きく上昇しないことあある25)。

MERS患者の病室に扔ける感染リスクを評価した 研究では, 看護師や医療従事者や家族など近くで患 
者と接する人の感染リスクは換気回数が 6 回/hから 12回/hに増えても数\%しか減らない一方で, 同室の 離れた場所にいる他の患者のリスクは半分近くまで 減少すると推定されている ${ }^{26}$ 。

一般住宅で日常生活を送っている時の換気回数で は, 数 $\mu \mathrm{m}$ 以下の粒子に対しては, 数十分〜数時間曝 露され続けることとなる。このことから, 定常的も しくは断続的に発生が想定される場合には, 常時空 開けをしておくことが望ましい。ただし，季節や部 屋の目的によっては常時の空開けが困難なケースも 考えられる。そのような場合には，一定時間ごとの 空開け換気をすることとなるが, 曝露を減らす対策 としては不十分な可能性むある。

換気によって屋外に排出された空気中にウィルス が含まれている場合も, 多くの場合は外気によって 非常に高倍率で希釈されるため, 屋外での感染には 寄与しないと考えられる。ただし, 排気口のすぐそ ばに喫煙所などの人が集まる場所がある場合や，排 気口のすぐそばに吸気口がある場合などには，注意 が必要なケースもあるかもしれない。

\section{6. 室内空気の清浄化}

フィルターによる粒径別粒子の捕集効率は, 100 $\mathrm{nm}$ 前後で非常に低く, 数 $\mu \mathrm{m}$ 以上や10 $\mathrm{nm}$ 以下では 非常に高い27)。ただし, 粒子捕集効率はフィルター によって大きく異なっており，40\% ASHRAEフィ ルター, 85\% ASHRAEフィルター, 標準ファーネス フィルターの粒子捕集効率は, $10 \mathrm{~nm}$ 以下の粒子で は，それぞれ $40 \%-100 \% ， 40 \%-100 \% ， 100 \%$ ，数 10 $\mathrm{nm}$-数 $100 \mathrm{~nm}$ の粒子で $10 \%$ 以下， $20 \%$ 以下， $40 \%$ $80 \%$, 数 $\mu \mathrm{m}$ 以上の粒子では $80 \%-100 \%, 100 \%, 100 \%$ だったという報告もある27)。(ASHRAEは，アメリカ 暖房冷凍空調学会のことで, 空調システムや換気な どに関する各種規格の策定もしている組織。 $40 \%$ ASHRAEフィルター及び $85 \%$ ASHRAEフィルター は, ASHRAEの標準ダストの平均捕集効率が $40 \%$ 及 び $85 \%$ の紙製プリーツフィルターである。標準ファー ネスフィルターは, 厚紙フレーム中に紡糸グラスファ イバーを組み込んだフィルターである $\left.{ }^{28}\right)$ 。静電フィ ルターでは，これらのサブミクロン領域の低捕集効 率が改善され，0.03-0.6 $\mu \mathrm{m}$ の粒子の捕集効率は, 市 販のHEPAフィルターでそれ以上ではほぼ $100 \%$ $(0.03 \mu \mathrm{m}$ の $97 \%$ 程度, 放電状態では40\%-90\%), 作 成したCMフィルターで $85 \%$ 以上(放電状態では $30 \%$ -
$80 \%$ ), 市販のMERV13フィルターで $60 \%$ 以上(放電状 態では数\%-25\%) と向上している ${ }^{29}$ 。ちなみに， HEPAフィルターは, JIS(日本工業規格)で粒径 0.3 $\mu \mathrm{m}$ の粒子の捕集効率が $99.97 \%$ 以上とされるフィル ターである。CMフィルターはこの研究において作 成された市販でない複合素材でのフィルターである。 MERVは, 米国のフィルターの規格(ASHRAE 52.2 (2007))で, MERV 1からMERV 16まであり, MERVE 13は0.3-1 $\mu \mathrm{m}$ の粒子の捕集効率が $75 \%$ 以下とされて いる。MERVE16は，0.3-1 $\mu \mathrm{m}$ の粒子の捕集効率が95 \%以上である。市販の空気清浄機は, 数 $\mathrm{m}^{3} /$ 分から 10 $\mathrm{m}^{3} /$ 分のため, HEPAフィルターが搭載されているも のであれば, 12畳の部屋で3-15回/h程度の換気に相 当する可能性がある。 HVACシステムでフィルター を通して空気清浄化を行った場合(循環回数0.8-0.9 回/h)，咳を模した装置から発生するウイルス(バク テリオファージ T4)の気中濃度は, $0.5 \mathrm{~m}$ 離れた位 置では3 種類のどのフィルターでも $20 \%$ 程度しか減 少せず，3 m離れた位置では20\%-80\%，5 m離れた 位置では70\%-98\%，12\%-92\%とフィルターごとに大 きく異なる効率で減少したと報告されている30) (HVACシステムは, 暖房・換気・エアコンの機能を 一体化したシステム)。HEPAフィルターを搭載した 大型の空気清浄化システムを使用した場合(51回/h), ウィルス(バクテリオファージ MS2)を含むエアロ ゾル発生器から発生させたウィルスはバクテリアや カビよりは除去効率が低いものの, 95\%が除去され たとする報告あある31)。ただし, HEPAフィルター あ製品によって性能に違いがあり, ウィルスの種類 によって効果が小さい場合あありうる。これらのこ とから, 空気清浄機を使用する場合にも, 換気との 併用が望ましい。また, フィルターの取り換え時の 曝露が懸念されるため, フィル夕ーの交換は手袋や マスクをした上で, 屋外に打いて行うべきだと思わ れる。

\section{7. 室内における沈着と再飛散}

大きな粒子では重力沈降により床面に沈着したり 移流により壁面に沈着したりすることが多く，小さ な粒子では拡散により床面だけでなく天井や壁面や 家具などの表面に沈着することが多い。100 $\mu \mathrm{m}, 10$ $\mu \mathrm{m}, 0.1 \mu \mathrm{m}$ の粒子の床面に沈着する割合は $43 \%-79$ $\%, 0.6 \%-18 \%, 2.5 \%-18 \%$, 壁面に沈着する割合は 8.7 $\%-47 \%, 51 \%-86 \%, 51 \%-89 \%$ とする研究あある ${ }^{15)}$ 
ウィルス(バクテリオファージ T4)の床面への沈 着は, 大きな大腸菌のケースと違い, 咳をした近く (0.5 m)では少なく, $3 \mathrm{~m}$ 離れた位置で高く, $5 \mathrm{~m}$ 離 れた地点でも $0.5 \mathrm{~m}$ の地点より高という報告があ る ${ }^{30)}$ 。大きい飛沫は重力沈降により数秒から15秒程 度で床面に沈着する ${ }^{14)}$ 。ちなみに, 温度 $21-23^{\circ} \mathrm{C}$ 相対 湿度 $40 \%$ の実験室で行った実験では, 銅, 段ボール 紙，ステンレス鋼，プラスチックの表面における新 型コロナウィルス (SARS-CoV-2)の生存半減期の中 央值は，0.77時間，3.5時間，5.6時間，6.8時間であ $3^{21)}$ 。他にも, 温度 $22^{\circ} \mathrm{C}$ 相対湿度 $65 \%$ の実験室にお いて, 新型コロナウイルス(SARS-CoV-2)を含む液を 表面に滴下したところ, 印刷用紙とティッシュペー パでは3時間後まで，木材や布は2日後まで，ガラス や紙幣は4日後まで，ステンレス鋼やプラスチック は7日後まで活性を有していた(初期值の〜0.1\%) と する報告あある ${ }^{32}$ 。ただし，これらは実験室内でコ ントロールされた条件下の試験であり, 実環境中で は温度・湿度・紫外線の影響をウィルスが受けうる ことや, ウィルスの活性を調べているがヒトへ感染 するかどうかを調べている試験ではない。新型コロ ナウィルス(SARS-CoV-2)の患者の病室において,ド アノブやベッドレールなどの手の触れるところだけ でなく, 床や空や排気ファンなど沈着したと考えら れる箇所からあウィルスが検出されている, ${ }^{5,12)}$ 。室 内の床面や各種表面に沈着したウィルスからの接触 感染の可能性もあるため, 床面やテーブル等の表面 について殺菌を定期的に行うことが必要と考えられ る。

室内の床面上のダストは, 歩行やドアの開閉や掃 除などの人の活動によって再飛散(巻き上げられる こと)が起こる ${ }^{33)} 。$ ダストのサイズ・性状や床面の材 質や環境条件によって, 再飛散率は大きく異なるが, 金属粒子などのダストの再飛散率は $0.000001 \%-0.1 \%$, カビやバクテリアなどの再飛散率は $0.0001 \%-0.1 \%$ と されている33)。ウィルス(バクテリオファージ T4)を 用いた試験では, ウィルスが検出された床上を歩い た時の気中のウィルス濃度は検出下限以下だったと されている

\section{8. 結言}

感染者が呼吸・会話・咳・くしゃみなどをすると， ウィルスを含む飛沫が環境中に飛散する。会話や咳 で飛散する大きな粒子は, 多くの場合 $2 \mathrm{~m}$ 以内に床
面に沈着するが, 室内の気流によっては5 m程度飛 散することあある。また，飛沫核などの小さな粒子 は，沈着せずに数時間もしくはそれ以上室内を漂う 可能性がある。室内空気中からウィルスが除去され る経路としては, 床面や壁面への沈着, 換気による 屋外への排出，ウィルスの不活化があるが，10 $\mu \mathrm{m}$ を超えるサイズの粒子ではほぼ沈着で除去されるが, 数 $\mu \mathrm{m}$ 以下の粒子では換気と不活化の寄与が大きい。 室内を漂うエアロゾル上の新型コロナウィルスの不 活化の半減期は 1.1 時間程度であり, 換気回数 1 回 $/ \mathrm{h}$ で減らせるエアロゾル量よりあ小さい。日本の一般 家屋の日常生活時の換気回数は，春夏で1.2-1.7回/h, 秋冬で0.6回/h程度であり, 病室などで感染対策とし て取られる換気回数よりはるかに低い。空開け換気 は室内濃度を低減させるのに非常に有効であるが， 屋外の風向や風速によっては十分な換気量が得られ ないケースもある。空気清浄機については，コロナ ウィルスについての研究はないが, ウィルスについ ても一定の効果が認められているため, 有用である 可能性はあるが，換気との併用が推奨される。マス クについては, 別の機会に整理したいが, 感染者か らの感染リスクの低減効果は大きい。

※WHOにおける用語の定義 ${ }^{1)}$

- 接触感染(contact transmission)

直接接触( direct contact) と間接接触 (indirect contact)による感染(transmission)

- 飛沫感染(droplet transmission)

主に<1 mの距離で生じる飛沫(droplet)による 感染

- 空気感染(airborne transmission)

飛沫核(droplet nuclei)の飛散・吸入による感染

- 飛沫(droplet)

$5 \mu \mathrm{m}$ り大きい吸入性エアロゾル

- 飛沫核(droplet nuclei)

$5 \mu \mathrm{m} よ り 小 さ い$ 吸入性エアロゾルで飛沫が乾 燥した吸入性エアロゾル残渣(residue of dried respiratory aerosols)

- 感染性吸入性エアロゾル (infectious respiratory aerosols)

吸入可能なサイズの感染性の飛沫と飛沫核

\section{謝辞}

本稿は, 室内環境学会ホームページにおいて公開 
した情報を改変したものである。公開に先駆けては, 室内環境学会学術委員会や理事会からのコメントに 従って修正した。学術委員会の川上裕司先生(株式 会社エフシージー総合研究所), 清水一男先生(静岡 大学), 池田四郎先生(株式会社ガステック), 野㠃淳 夫先生(東北文化学園大学大学院), 中島大介先生(国 立研究開発法人国立環境研究所), 北條祥子先生(東 北大学大学院歯学研究科), 水越厚史先生(近畿大学 医学部), 徳村雅弘先生(静岡県立大学), 高木麻衣先 生(国立研究開発法人国立環境研究所), 理事会の関 根嘉香先生(東海大学), 山口一先生(大同大学), 鍵直 樹先生(東京工業大学), 三宅祐一先生(静岡県立大学) に深く感謝する。

\section{引用文献}

1) World Health Organization: Infection prevention and control of epidemic- and pandemic-prone acute respiratory infections in health care, Geneva: World Health Organization (2014). https://apps.who.int/iris/ bitstream/handle/10665/112656/9789241507134_eng. pdf? sequence $=1$

2) Chan J. F. W., Yuan S. F., Kok K. H., To K. K. W., Chu H., Yang J., Xing F. F., Liu J. L., Yip C. C. Y., Poon R. W. S., Tsoi H. W., Lo S. K. F., Chan K. H. Poon V. K. M., Chan W. M., Ip J. D., Cheng V. C. C., Chen H. L., Hui C. K. M., Yuen K. Y.: A familial cluster of pneumonia associated with the 2019 novel coronavirus indicating person-to-person transmission: a study of a family cluster, Lancet, 395, 514-523 (2020).

3) Li Q., Guan X. H., Wu P., Wang X. Y., Zhou L., Tong Y. Q., Ren R. Q., Leung K. S. M., Lau E. H. Y., Wong J. Y., Xing X. S., Xiang N. J., Wu Y., Li C., Chen Q., Li D., Liu T., Zhao J., Liu M., Tu W. X., Chen C. D., Jin L. M., Yang R., Wang Q., Zhou S. H., Wang R., Liu H., Luo Y. B., Liu Y., Shao G., Li H., Tao Z. F., Yang Y., Deng Z. Q., Liu B. X., Ma Z. T., Zhang Y. P., Shi G. Q., Lam T. T. Y., Wu J. T., Gao G. F., Cowling B. J., Yang B., Leung G. M., Feng Z. J.: Early transmission dynamics in Wuhan, China, of novel coronavirus-infected pneumonia, The New England Journal of Medicine, 382, 1199-1207 (2020).

4) Huang C. L., Wang Y. M., Li X. W., Ren L. L.,
Zhao J. P., Hu Y., Zhang L., Fan G. H., Xu J. Y., Gu X. Y., Cheng Z. S., Yu T., Xia J. A., Wei Y., Wu W. J., Xie X. L., Yin W., Li H., Liu M., Xiao Y., Gao H., Guo L., Xie J. G., Wang G. F., Jiang R. M., Gao Z. C., Jin Q., Wang J. W., Cao B.: Clinical features of patients infected with 2019 novel coronavirus in Wuhan, China, Lancet, 395, 497-506 (2020).

5) Ong S. W. X., Tan Y. K., Chia P. Y., Lee T. H., Ng O. T., Wong M. S. Y., Marimuthu K.: Air, Surface Environmental, and Personal Protective Equipment Contamination by Severe Acute Respiratory Syndrome Coronavirus 2 (SARS-CoV-2) From a Symptomatic Patient, JAMA, E1-E3 (2020).

6) World Health Organization: Report of the WHOChina Joint Mission on Coronavirus Disease 2019 (COVID-19) 16-24 February 2020 (2020). https:// www.who.int/docs/default-source/coronaviruse/whochina-joint-mission-on-covid-19-final-report.pdf

7) Bella J., Rossmann M. G.: Review: Rhinoviruses and their ICAM receptors, Journal of Structural Biology, 128, 69-74 (1999).

8) Noda T.: Native morphology of influenza virions. Frontiers in Microbiology, 3, 269 (2012).

9) Chen N. S., Zhou M., Dong X., Qu J. M., Gong F. Y., Han Y., Qiu Y., Wang J. L., Liu Y., Wei Y., Xia J. A., Yu T., Zhang X. X., Zhang L.: Epidemiological and clinical characteristics of 99 cases of 2019 novel coronavirus pneumonia in Wuhan, China: a descriptive study, Lancet, 395: 507-513 (2020).

10) Johnson G. R., Morawska L., Ristovski Z. D., Hargreaves M., Mengersen K., Chao C. Y. H., Wan M. P., Li Y., Xie X., Katoshevski D., Corbett S.: Modality of human expired aerosol size distributions, Journal of Aerosol Science, 42, 839-851 (2011).

11) Lindsley W. G., Pearce T. A., Hudnall J. B., Davis K. A., Davis S. M., Fisher M. A., Khakoo R., Palmer J. E., Clark K. E., Celik I., Coffey C. C., Blachere F. M., Beezhold D. H.: Quantity and Size Distribution of Cough-Generated Aerosol Particles Produced by Influenza Patients During and After Illness, Journal of Occupational and Environmental Hygiene, 9, 443-449 (2012). 
12) Chia P. Y., Coleman K. K., Tan Y. K., Wei S., Ong X., Gum M., Lau S. K., Sutjipto S., Lee P. H., Son T. T., Young B. E., Milton D. K., Gray G. C., Schuster S., Barkham T., De P. P., Vasoo S., Chan M., Ang B. S. P., Tan B. H., Leo Y.-S., Ng O.-T., Wong M. S. Y., Marimuthu K.: Detection of Air and Surface Contamination by Severe Acute Respiratory Syndrome Coronavirus 2 (SARS-CoV-2) in Hospital Rooms of Infected Patients, (Preprint from BioRXiv) (2020). https://doi.org/10.1101/2020.03.29. 20046557doi

13) Liu Y., Ning Z., Chen Y., Guo M., Liu Y., Gali N. K., Sun L., Duan Y., Cai J., Westerdahl D., Liu X., Ho K.-F., Kan H., Fu Q., Lan K.: Aerodynamic Characteristics and RNA Concentration of SARSCoV-2 Aerosol in Wuhan Hospitals during COVID19 Outbreak, (Preprint from BioRXiv) (2020). https://doi.org/10.1101/2020.03.08.982637

14) Xie X., Li Y., Chwan A. T. Y., Ho P. L., Seto W. H.: How far droplets can move in indoor environments - revisiting the Wells evaporation-falling curve, Indoor air, 17, 211-225 (2007).

15) Chen C. and Zhao B.: Some questions on dispersion of human exhaled droplets in ventilation room: answers from numerical investigation, Indoor Air, 20, 95-111 (2010).

16) Lu J., Gu J., Li K., Xu C., Su W., Lai Z., Zhou D., Yu C., Xu B., Yang Z.: COVID-19 Outbreak Associated with Air Conditioning in Restaurant, Guangzhou, China, 2020, Emerging Infectious Diseases, 26, in print (2020). https://doi.org/10.3201/ eid2607.200764

17) Morawska L., Johnson G. R., Ristovski Z. D., Hargreaves M., Mengersen K., Corbett S., Chao C. Y. H., Li Y., Katoshevski D.: Size distribution and sites of origin of droplets expelled from the human respiratory tract during expiratory activities, Journal of Aerosol Science, 40, 256-269 (2009).

18) Nicas M., Nazaroff W. W., Hubbard A.: Toward understanding the risk of secondary airborne infection: emission of respirable pathogens, Journal of Occupational and Environmental Hygiene, 2, 143 154 (2005).

19) Shaughnessy R.: Transmission of Viruses in
Droplets and Aerosols, ISIAQ Webinar, April 14, 2020.

20) Yang W., Marr L. C.: Dynamics of Airborne Influenza A Viruses Indoors and Dependence on Humidity. PlosOne, 6, e21481 (2011).

21) van Doremalen N, Bushmaker T, Morris D. H., Holbrook M. G., Gamble A., Williamson B. N., Tamin A., Harcourt J. L., Thornburg N. J., Gerber S. I., Lloyd-Smith J. O., de Wit E., Munster V. J.: Aerosol and Surface Stability of SARS-CoV-2 as Compared with SARS-CoV-1, The New England Journal of Medicine, 382, 1564-1567 (2020). https://www.nejm.org/doi/pdf/10.1056/NEJMc2004973

22) Shinohara N., Kataoka T., Takamine K., Gamo M.: Distribution and variability of the 24-h average air exchange rates and interzonal flow rates in 26 Japanese residences over 5 seasons, Atmospheric Environment, 45, 3548-3552 (2011).

23) Hou J., Zhang Y. F., Sun Y. X., Wang P., Zhang Q. N., Kong X. R., Sundell J.: Air change rates at night in northeast Chinese homes, Building and Environment, 132, 273-281 (2018).

24) Xiao Y., Wang L. N., Yu M. Z., Liu H., Liu J.: Effects of source emission and window opening on winter indoor particle concentrations in the severe cold region of China, Building and Environment, 144, 23-33 (2018).

25) Wang J. H., Zhang T. F., Wang S. G., Battaglia F.: Numerical investigation of single-sided natural ventilation driven by buoyancy and wind through variable window configurations, Energy and Buildings, 168, 147-164 (2018).

26) Adhikari U., Chabrelie A., Weir M., Boehnke K., McKenzie E., Ikner L., Wang M., Wang Q., Young K., Haas C. N., Rose J., Mitchell J.: A Case Study Evaluating the Risk of Infection from Middle Eastern Respiratory Syndrome Coronavirus (MERS$\mathrm{CoV}$ ) in a Hospital Setting Through Bioaerosols, Risk Analysis, 39, 2608-2624 (2019).

27) Riley W. J., McKone T. E., Lai A. C. K., Nazaroff W. W.: Indoor particulate matter of outdoor origin: Importance of size-dependent removal mechanisms, Environmental Science \& Technology, 36, 200-207 (2002). 
28) Hanley J. T., Ensor D. S., Smith D. D., Sparks L. E.: Fractional Aerosol Filtration Efficiency of InDuct Ventilation Air Cleaners, Indoor Air, 4, 169178 (1991).

29) Li S. H., Chen D. R., Zhou F. B., Chen S. C.: Effects of relative humidity and particle hygroscopicity on the initial efficiency and aging characteristics of electret HVAC filter media, Building and Environment, 171, 106669 (2020).

30) Kunkel S. A., Azimi P., Zhao H., Stark B. C., Stephens B.: Quantifying the size-resolved dynamics of indoor bioaerosol transport and control, Indoor Air, 27, 977-987 (2017).

31) Foarde K. K., Hanley J. T., Ensor D. S., Roessler P.:
Development of a method for measuring single-pass bioaerosol removal efficiencies of a room air cleaner, Aerosol Science and Technology, 30, 223234 (1999).

32) Chin A. W. H., Chu J. T. S., Perera M. R. A., Hui K. P. Y., Yen H.-L., Chan M. C. W., Peiris M., Poon L. L. M.: Stability of SARS-CoV-2 in different environmental conditions. Lancet microbe, 1, e10 (2020). https://doi.org/10.1016/S2666-5247(20) 30003-3

33) Qian J., Peccia J., Ferro A. R.: Walking-induced particle resuspension in indoor environments, Atmospheric environment, 89, 464-481 (2014). 